Original Article

\title{
Population attributes of Littoraria angulifera (Gastropoda: Littorinidae) in mangroves in Bahia State, northeastern Brazil
}

\author{
Atributos populacionais de Littoraria angulifera (Gastropoda: Littorinidae) em \\ manguezais no estado da Bahia, Nordeste do Brasil \\ G. Boehs ${ }^{\mathrm{a}, \mathrm{b} *}$ (i) and L. A. de Freitas ${ }^{\mathrm{b}}$ (D) \\ a Universidade Estadual de Santa Cruz - UESC, Departamento de Ciências Biológicas - DCB, Ilhéus, BA, Brasil

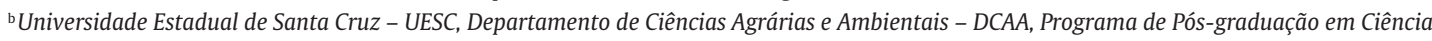 \\ Animal, lhéus, BA, Brasil
}

\begin{abstract}
Littoraria angulifera (Lamarck, 1822) is an estuarine gastropod of tropical occurrence, which lives mainly on trunks of mangrove tree species. This study aimed to evaluate the population attributes of this species, such as abundance, space-time distribution, sex ratio and recruitment in mangroves in Bahia State, northeastern Brazil. The specimens were collected monthly throughout 2018, on trunks of the red mangrove Rhizophora mangle L. at two heights and on two horizontal levels. Specimens that were on the marine grass Spartina alterniflora Loisel were also collected. After counting, biometrics and sexing, the specimens were returned alive to the environment. The average size and weight of $L$. angulifera was higher $(\mathrm{p}<0.05)$ in places with taller and less sparse trees and the vertical distribution on the trunks showed a preference for strata close to the soil. Both results are related to shading and protection against desiccation. Females were more abundant than males, at an approximate sex ratio F: M of 1.4: 1. Recruits were observed throughout the period, showing continuous reproduction of the species with a recruitment peak in spring (September to November). The study revealed the importance of keep the mangroves intact to allow the maintenance of the natural stocks of the species.
\end{abstract}

Keywords: ecology, caenogastropods, Littorinimorpha, recruitment, reproduction.

\begin{abstract}
Resumo
Littoraria angulifera (Lamarck, 1822) é um gastrópode estuarino, de ocorrência tropical, que vive principalmente sobre troncos de espécies arbóreas de mangue. Este estudo teve como objetivo avaliar os atributos populacionais dessa espécie, como abundância, distribuição espaço-temporal, razão sexual e recrutamento em manguezais do estado da Bahia, nordeste do Brasil. Os espécimes foram coletados mensalmente ao longo de 2018, em troncos do mangue vermelho Rhizophora mangle L. em duas alturas e em dois níveis horizontais. Também foram coletados espécimes que estavam na grama marinha Spartina alterniflora Loisel. Após contagem, biometria e sexagem, os espécimes foram devolvidos vivos ao ambiente. $O$ tamanho e peso médios de L. angulifera foram maiores $(\mathrm{p}<0,05)$ em locais com árvores mais altas e menos esparsas e a distribuição vertical nos troncos mostrou preferência por estratos próximos ao solo. Ambos os resultados estão relacionados ao sombreamento e proteção contra a dessecação. As fêmeas foram mais abundantes que os machos, em uma proporção sexual aproximada F: M de 1,4: 1. Recrutas foram observados ao longo do período, mostrando reprodução contínua da espécie, com um pico de recrutamento na primavera (setembro a novembro). 0 estudo revelou a importância de manter os manguezais intactos para permitir a manutenção dos estoques naturais da espécie.
\end{abstract}

Palavras-chave: ecologia, caenogastrópodes, Littorinimorpha, recrutamento, reprodução.

\section{Introduction}

Gastropods of the Littorinidae family are amphibious mollusks living on hard substrates, withstand long periods out of water, and feed on microscopic algae (Rios, 2009). Littoraria angulifera (Lamarck, 1822) belongs to a group of Littorinidae (subgenus Littorinopsis Mörch, 1876) who inhabit mangroves, that are ovoviviparous and having internal fertilization (Gallagher and Reid, 1979), being that males have a well developed penis with an open but folded sperm duct (Rios, 2009).

According to Zeidan et al. (2020), the penis of L. angulifera is yellow in color and located behind the right eye tentacle and reaches length up to $9.98 \mathrm{~mm}$. The species reaches $30 \mathrm{~mm}$ of shell height, whose surface is sculptured with very fine spiral striations (Rios, 2009), with color

*e-mail: gboehs@uesc.br; guislaboehs@hotmail.com

Received: September 2, 2020 - Accepted: October 30, 2020

This is an Open Access article distributed under the terms of the Creative Commons Attribution License, which permits unrestricted use, distribution, and reproduction in any medium, provided the original work is properly cited. 
polymorphism, but with dark brown predominating (Zeidan et al., 2020). It presents detritivorous/ microphagic habit (Gutierrez, 1988), feeding mainly on lichens and fungi (Kohlmeyer and Bebout, 1986).

Also known as mangrove periwinkle, L. angulifera has a range of distribution from Florida to Brazil, throughout the Caribbean and Bermuda (Abbott and Morris, 1995) and the species occurs also in eastern Atlantic from Senegal to Angola (Kohlmeyer and Bebout, 1986; Merkt and Ellison, 1998). According to Rios (2009), on the Brazilian coast, the occurrence of the species extends from the state of Ceará to the state of São Paulo. In a study carried out a little further south, Boehs et al. (2004) found the species, in low density, in a non-vegetated tidal flat of Paranaguá Bay (State of Paraná), still in a tropical region, in transition to the subtropical climate.

Several studies carried out in the last years (e.g., Melo et al., 2012; Costa et al., 2013; Martínez et al., 2013; Zeidan et al., 2020) in different Brazilian regions indicate that $L$. angulifera shows suitability as a bio-indicator species, that is, it presents evident morphological responses to environmental heterogeneities in micro regions within the same mangrove and among different mangroves and also to different stressors of anthropogenic origin, such as deforestation, biological contaminants and chemical pollutants. This could reflect, for example, the size and weight of the animals and also the texture of the shell (more fragile or more robust) and possibly can affect reproduction. In this context, although several studies have been carried out on this species, there are still many questions to answer about basic biological and ecological characteristics related to it, such as, for example, the sex ratio in different populations, the spatial distribution of males and females in the mangroves and the variation in shell size in different mangrove forests. There is also a lack of information on recruitment periods. The answers to these questions seem to us to be important for a better understanding of management, conservation and use of the species in mangroves monitoring.

In this study, we aimed to investigate if: (i) the height of mangrove trees have an influence on the size and abundance of L. angulifera; (ii) larger animals occupy higher strata in the trees; (iii) males and females have a distinct spatial distribution; (iv) to facilitate the elimination of larvae, females are more concentrated near the water line; (v) the expected male to female sex ratio is $1: 1$; (vi) as it is a tropical area, continuous reproduction of the species is expected, with peaks of reproduction in warmer periods of the year. Based on these assumptions, the scope of this study was to carry out an assessment of the spatial and temporal distribution, as well as analyzing the size structure and sex ratio of $L$. angulifera in mangroves in southern Bahia, Brazil.

\section{Material and Methods}

The study was conducted in two mangroves located in the municipalities of Ilhéus ( $14^{\circ} 88^{\prime} 33.38^{\prime \prime} \mathrm{S}$; $\left.39^{\circ} 02^{\prime} 06.45^{\prime \prime W}\right)$ and Uruçuca (14 $34^{\prime} 26.25^{\prime \prime}$; $\left.39^{\circ} 3^{\prime} 8.20^{\prime \prime} \mathrm{W}\right)$, in southern Bahia (northeastern Brazil), in the study denominated
Mangrove 1 (M1) and Mangrove 2 (M2), respectively (Figure 1). The sampling of biological material and information on environmental parameters were previously authorized by the Chico Mendes Institute for Biodiversity and Conservation (ICMBio-Brazil), under License number 62043-1/2018. All animals, after counting, sexed, measured and weighed, were returned alive to mangroves. Sampling was carried out in all months of 2018, always during low spring tide, when the mangroves were emerged.

For the purposes of environmental characterization, at each beginning and end of sampling, measurements were taken of air and water temperature (with a standard mercury thermometer) and of salinity (with an Atago S/Mill optical refractometer) of the adjacent water (river) to the mangroves. Data on monthly accumulated rainfall during the year were obtained from CLIMATEMPO (2020) records.

A pilot study, carried out in January 2018, served as a basis for the sample design and showed that L. angulifera occupies a height of about $2 \mathrm{~m}$ on the tree trunks and that it can also occur in undergrowth (marine grasses) when present. The sampling design was the same in both mangroves and consisted of the initial establishment, using a measuring tape, of three transects with $30 \mathrm{~m}$ each $(25 \mathrm{~m}$ equidistant from each other) starting from the waterline towards the interior of the mangrove. Then, two horizontal levels were established from the central transect, each measuring $50 \mathrm{~m}$, being level 1 (L1) a few meters from the river and level 2 (L2), $20 \mathrm{~m}$ from L1, towards the interior of the mangrove. The transect methodology was adapted from Boehs et al. (2004). Samples of $L$. angulifera were made monthly on five mangrove trees at each sampling level, which were randomly chosen at each month. The trunks were measured with a tape measure as to their circumference at a height of about $1 \mathrm{~m}$ and the height of the trees was estimated using a measuring tape adapted to a wood bar.

Two lots of animals were manually collected by two same collectors, Lot A consisting of collection of specimens arranged on the trunks and aerial roots of the trees and the animals of Lot B those adhering to undergrowth (grasses), when present, within a radius of about $2 \mathrm{~m}$ from each drawn tree. On the trunks, $L$. angulifera was collected in two different strata of height: in $\mathrm{H} 1$, from the soil to $1 \mathrm{~m}$ in height and in $\mathrm{H} 2$, from 1 to $2 \mathrm{~m}$, and all those animals seen were included in the sampling. Considering Lot A, 20 samples of $L$. angulifera were obtained at each locality (mangrove) per month (L1H1 = 5 + L1H2 = 5 + L2H1 = $5+\mathrm{L} 2 \mathrm{H} 2=5$ ), totaling 240 samples/sampling station considering the entire sampling period. The snails were placed alive in identified polypropylene containers, which were previously perforated for natural aeration and closed with lids. The samples were immediately transported to the Marine Mollusk Laboratory/Santa Cruz State University (LMM/UESC) where they were stored at room temperature in the transport containers until the next day, when the animals were processed.

The laboratory routine included (i) the measurement, with a digital caliper with a precision of $0.01 \mathrm{~mm}$, of the main axis of the shell (height = distance between the apex of the shell and the posterior edge of the aperture; Rios, 2009) of all specimens collected in the respective substrates 
(Lots A and B); (ii) anesthesia with 10\% Magnesium Chloride $\left(\mathrm{MgCl}_{2}\right)$ in distilled water (Lots A and B), a procedure that does not cause damage or death to the animal, but which facilitates the handling of specimens (Zeidan et al., 2018); (iii) weighing with shell on scale (Marte, with precision of 0.001g) (Lot A) and (iv) sexing (Lot A), with the naked eye, using the presence/absence of the penis as a visual parameter.

The animals in Lot A, as well as the height and diameter information of the forest vegetation, were analyzed by descriptive statistics and also by ANOVA One-Way followed
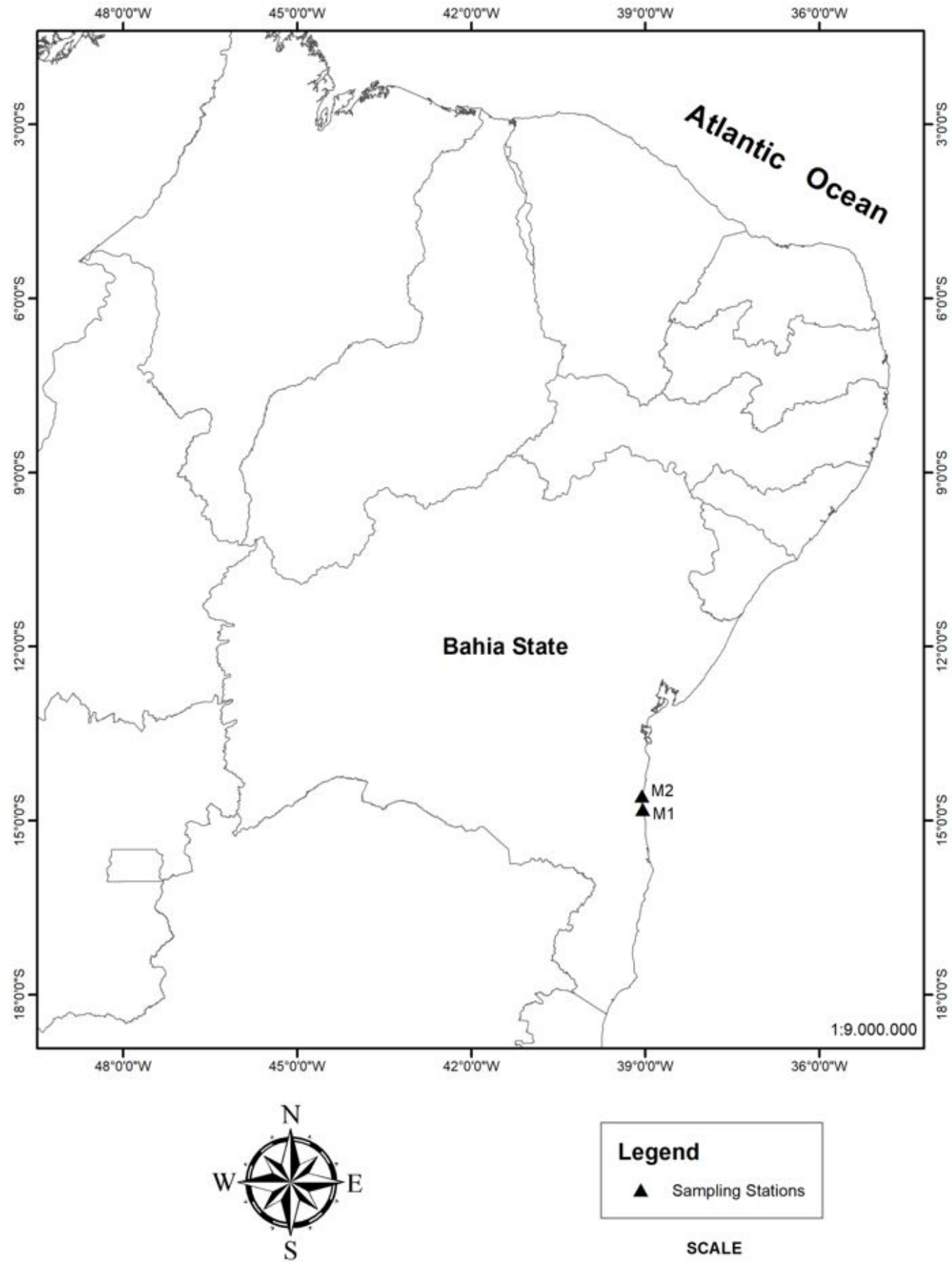

\section{Legend}

A Sampling Stations

SCALE

Coordinate System: GCS WGS 1984

Datum: WGS 1984

Units: Degree

Figure 1. Map of northeastern Brazil showing the location of the Bahia State and the sampling stations (M1 and M2). 
by Tukey's test when convenient. The sexual proportion was tested through Pearson's Chi-square test. The alpha value adopted was 0.05 . The data of time variation of L. angulifera in the mangroves were analyzed by R software and all other analyzes by BioEstat 5.0. The shell height data for Lot B were interpreted by visual analysis of monthly size frequency histograms. The shell height references for categorizing recruits were based on Chaves (2002), with modifications. To obtain an image of $L$. angulifera shell from the region, please consult Zeidan et al. (2020).

\section{Results}

\subsection{Environmental abiotic characterization}

The air temperature varied between 21 and $31^{\circ} \mathrm{C}$ in $\mathrm{M} 1\left(\right.$ Mean $=26.6^{\circ} \mathrm{C}$, Standard Deviation $\left.-\mathrm{SD} \pm 2.9 ; \mathrm{N}=24\right)$ and between 22 and $35^{\circ} \mathrm{C}$ in $\mathrm{M} 2$ (Mean $=27.3^{\circ} \mathrm{C}, \mathrm{SD} \pm 3.8$; $\mathrm{N}=24$ ), with annual median of 26 and $27^{\circ} \mathrm{C}$, respectively and similarity between mangroves $(\mathrm{F}=3.5513$; $\mathrm{p}>0.05)$. The water temperature ranged from 22 to $30^{\circ} \mathrm{C}$ in $\mathrm{M} 1$ (Mean $=25.3^{\circ} \mathrm{C}, \mathrm{SD} \pm 2.1 ; \mathrm{N}=24$ ) and from 21 to $32^{\circ} \mathrm{C}$ in $\mathrm{M} 2\left(\right.$ Mean $\left.=26.6^{\circ} \mathrm{C}, \mathrm{SD} \pm 2.8 ; \mathrm{N}=24\right)$, with annual median of 25.5 and $26^{\circ} \mathrm{C}$, respectively $(\mathrm{F}=0.4751 ; \mathrm{p}>0.05)$.

Salinity showed a significant annual variation in both areas and also between the measurements made at the beginning (peak of low tide) and at the end of collections (beginning of high tide). In M1, this ranged from zero to 15 (Mean $=5.8, \mathrm{SD} \pm 5.0 ; \mathrm{N}=24)$ and in M2 there was a minimum of zero and a maximum of 25 (Mean $=5.8$, $\mathrm{SD} \pm 7.8 ; \mathrm{N}=24$ ). As for rainfall, the annual average was $170 \mathrm{~mm} /$ month in 2018. Considering monthly accumulated values, the months with the highest levels of rainfall were March (217 mm), April (205 mm), June and July (both with $201 \mathrm{~mm})$ and December (179 mm).

\subsection{Littoraria angulifera substrates (vegetation)}

The trees on which specimens from Lot A were collected were all Rhizophora mangle L., the red mangrove. In M1 the trees were lower $(p<0.01)$ and also less thick $(p<0.05)$ in relation to $\mathrm{M} 2$, but there was homogeneity between the sample levels (L1 and L2) in each of the localities (Table 1). The minimum height recorded in M1 was $3.1 \mathrm{~m}$ and the maximum was $6.4 \mathrm{~m}$, and in M2, the heights varied from 3.1 to $12.26 \mathrm{~m}$, with the medians being 4.6 and $6.5 \mathrm{~m}$, respectively. Only in M1 was observed the marine grass Spartina alterniflora Loisel (Poaceae), with an average of approximately $20 \mathrm{~cm}$ in height, on which the animals of Lot $B$ were collected. The grass was irregularly distributed among the trees of $R$. mangle.

\subsection{Attributes of L. angulifera}

Considering the animals obtained in Lot A, collected on $R$. mangle trunks, 2,935 individuals were obtained in Mangrove 1 (M1) and 2,852 individuals in Mangrove 2 (M2) in the sum of data from the 12 collection campaigns, which resulted in statistical similarity between localities $(F=0.829 ; p>0.05)$. Throughout the year, a sharp fluctuation occurred in both populations, which was
Table 1. Mean values and standard deviation $( \pm S D)$ of the height and circumference of the red mangrove Rhizophora mangle on two horizontal levels (L1 and L2) of mangroves M1 and M2 on the coast of Bahia State, northeastern Brazil, based on the monthly biometry of 10 trees in each mangrove ( 5 L1 and 5 L2; $n$ total $=120$ / locality) throughout 2018.

\begin{tabular}{cccc}
\hline Mangroves & Levels & Height $(\mathbf{m})$ & $\begin{array}{c}\text { Circumference } \\
(\mathbf{m})\end{array}$ \\
\hline \multirow{2}{*}{ M1 } & L1 & $4.63 \pm 0.88$ & $0.19 \pm 0.08$ \\
& L2 & $4.55 \pm 0.58$ & $0.32 \pm 0.24$ \\
& L1+L2 & $4.61 \pm 0.72$ & $0.25 \pm 0.18$ \\
& L1 & $6.05 \pm 1.43$ & $0.24 \pm 0.14$ \\
M2 & L2 & $6.95 \pm 1.48$ & $0.70 \pm 0.25$ \\
& L1 + L2 & $6.59 \pm 1.49$ & $0.30 \pm 0.21$ \\
\hline
\end{tabular}

statistically significant both in M1 $(\mathrm{F}=4.431 ; \mathrm{p}<0.001)$ and in $\mathrm{M} 2$ ( $\mathrm{F}=2.952 ; \mathrm{p}<0.001)$, however, it was not possible establish the existence of any temporal pattern, similarity of distribution between populations or indication of seasonality.

In the analysis of spatial distribution, there was an inverse pattern between the mangroves: in M1 the number of periwinkles was higher in level L2 and in M2 it was higher in $\mathrm{L} 1(\mathrm{p}<0.05)$. In the vertical distribution, there was difference $(\mathrm{p}<0.01)$ between H1 (more basal) and H2 (1-2 m of trunk height), with a higher concentration of animals in $\mathrm{H} 1$ in both mangroves. In the comparison of the vertical levels between the two mangroves, the same levels (H1 or H2) were numerically similar to each other ( $p>0.05)$, showing that there was consistency in the vertical distribution of the species (Table 2 ).

Horizontal (L1 and L2) and vertical (H1 and H2) sampling levels were similar ( $p>0.05)$ in terms of height and weight of $L$. angulifera, for both males and females, in both localities (Table 3). In M1, the shell height of the animals measured between $0.55 \mathrm{~mm}$ (smallest specimen) and $30.35 \mathrm{~mm}$ (largest specimen) and in M2, the smallest height was $8.11 \mathrm{~mm}$ and the largest was $33.28 \mathrm{~mm}$ (Table 4). In M1 the mean height of the animals was $17 \mathrm{~mm}(\mathrm{SD} \pm 4.21)$ and in $\mathrm{M} 2$, it was $21.8 \mathrm{~mm}(\mathrm{SD} \pm 3.31)(\mathrm{p}<0.05$ between mangroves). In addition to being smaller, the shells of snails in M1 were generally more fragile and more brittle in comparison to animals in M2.

In the size comparisons between males and females, in $\mathrm{M} 1$ the mean height of males was $17.67 \mathrm{~mm}(\mathrm{SD} \pm 3.91$ ) and for females it was $16.33 \mathrm{~mm}(\mathrm{SD} \pm 4.52$ ), whereas in $\mathrm{M} 2$, the means were $22.09 \mathrm{~mm}(\mathrm{SD} \pm 2.94)$ and $21.68 \mathrm{~mm}$ ( $S D \pm 3.68)$, respectively. As shown in Table 4, males were, on average, larger than females in all months on M1. At that locality these differences were not significant ( $p>0.05$ ) only in August, September, October and December. In M2 this trend was maintained, being only in June, September and November, the differences in height were significant $(\mathrm{p}<0.05)$.

Still in Lot A, animals with a shell height below $9 \mathrm{~mm}$ (recruits) were observed on the trunks, but in small quantities. In M1, these individuals had the following monthly frequency: 4.7\% (January), 0.36\% (February), 
Table 2. Total number of Littoraria angulifera individuals (males and females) obtained throughout 2018 on Rhizophora mangle trunks in two mangroves (M1 and M2) on the coast of Bahia State, northeastern Brazil, showing the spatial distribution, being horizontal (levels L1 and L2) and vertical ( $\mathrm{H} 1=0-1 \mathrm{~m}$ height and $\mathrm{H} 2=1-2 \mathrm{~m}$ height on the trunks).

\begin{tabular}{ccccccccc}
\hline Mangroves & $\begin{array}{c}\text { Horizontal } \\
\text { levels }\end{array}$ & Males & Females & Totals & $\begin{array}{c}\text { Vertical } \\
\text { levels }\end{array}$ & Males & Females & Totals \\
\hline \multirow{2}{*}{ M1 } & L1 & 452 & 704 & 1,156 & H1 & 904 & 1,445 & 2,349 \\
& L2 & 731 & 1,048 & 1,779 & H2 & 279 & 307 & 586 \\
\multirow{2}{*}{ M2 } & L1 & 722 & 975 & 1,697 & H1 & 707 & 1,215 & 1,922 \\
& L2 & 462 & 693 & 1,155 & H2 & 477 & 453 & 930 \\
\hline
\end{tabular}

Table 3. Means and standard deviation $( \pm$ SD) of shell height $(\mathrm{mm})$ and total weight $(\mathrm{g})$ of Littoraria angulifera in 2018, being sums of males and females, in horizontal (L1 and L2) and vertical (H1 and H2) levels of two mangroves (M1 and M2) on coast of Bahia, northeastern Brazil.

\begin{tabular}{|c|c|c|c|c|c|}
\hline \multirow{2}{*}{ Parameters } & \multirow{2}{*}{ Mangroves } & \multicolumn{2}{|c|}{ Horizontal levels } & \multicolumn{2}{|c|}{ Vertical levels } \\
\hline & & L1 & L2 & H1 & H2 \\
\hline \multirow[t]{2}{*}{ Height (mm) } & M1 & $17.60 \pm 7.50$ & $16.31 \pm 4.43$ & $16.57 \pm 6.17$ & $17.81 \pm 4.28$ \\
\hline & M2 & $21.28 \pm 3.47$ & $22.82 \pm 6.61$ & $21.75 \pm 5.75$ & $22.21 \pm 3.07$ \\
\hline \multirow[t]{2}{*}{ Weight (g) } & M1 & $0.84 \pm 0.55$ & $0.76 \pm 0.79$ & $0.78 \pm 0.75$ & $0.82 \pm 0.49$ \\
\hline & M2 & $1.67 \pm 0.93$ & $1.94 \pm 1.06$ & $1.92 \pm 1.12$ & $1.98 \pm 0.64$ \\
\hline
\end{tabular}

3.15\% (March), 9.74\% (April), 3.5\% (May), 0.28\% (June), 3.72\% (July), 0.85\% (August), 11.21\% (September), 6.7\% (October), 4.48\% (November) and 7.07\% (December). In M2, animals in this size range on the trunks of $R$. mangle were seen only in the month of August, in a low percentage in relation to the rest of the sample $(0.37 \%)$. In this locality, even though recruits were observed in low frequency only in that month, animals of intermediate size (between 9 and $12 \mathrm{~mm}$ in height), were seen more frequently on this substrate in relation to recruits (Table 4). In general, individuals below $12 \mathrm{~mm}$ in size represented, on average, $19.01 \%$ of the total number of individuals in M1 and 2.43\% of the total number of individuals in M2. In both places, a decrease in the number of individuals from $24 \mathrm{~mm}$ in height, representing the old animals of the population, was noticeable. These animals represented, proportionally, $3.2 \%$ in $\mathrm{M} 1$ and $14.2 \%$ in M2.

In terms of sexual proportion, on the whole, females (F) were numerically dominant over males $(\mathrm{M})$ in both mangroves. In M1, the sex ratio (Male: Female) was 1: 1.48 (or $\mathrm{M}: \mathrm{F}=0.4)\left(\chi^{2}=38.572 ; \mathrm{p}<0.0001\right)$ and in $\mathrm{M} 2$ it was 1 : 1.4 (or $\mathrm{M}: \mathrm{F}=0.41)\left(\chi^{2}=54.077 ; \mathrm{p}<0.0001\right)$, considering the total number of animals. Males were more abundant than females only in February (M1) and March (M2), but with very small numerical differences with respect to these (Figure 2).

Lot B, obtained from the grass Spartina alterniflora of M1, was composed of specimens with shell height between $0.58 \mathrm{~mm}$ (smallest specimen) and $20.98 \mathrm{~mm}$ (largest specimen). On this substrate, post-larvae and juveniles, that is, individuals with a shell height below $9 \mathrm{~mm}$ (Classes C1-C3) (recruits) were evident throughout the year, generally in greater number in relation to larger animals, between 12 and $21 \mathrm{~mm}$ of shell height (C4-C7). In some months (October and November) the animals with shell height less than $3 \mathrm{~mm}$ (C1) were the only animals found on the grass. Animals in classes C6 and C7 (between 15 and $21 \mathrm{~mm}$ ) were uncommon in this vegetation (Figure 3).

\section{Discussion}

Littoraria angulifera has continuous reproduction in the region, which was evidenced by the entry of new small individuals in practically every month of the year, but in the spring (from September to November) there was a greater input of recruits, which is probably related to a small increase in temperature at this time of year, an abiotic factor that stimulates reproduction (Galtsoff, 1961). Burgett et al. (1987) observed the release of gametes on the Caribbean coast of Panama of this species for at least 10 months of the year, with peaks of release in spring and autumn. This gastropod is reported to have incomplete ovoviviparity, with egg retention in the mantle cavity until the veliger larval stage, when the larvae are released, along with some immature eggs, during high tide (Gallagher and Reid, 1979; Gutierrez, 1988; Merkt and Ellison, 1998). According to Gallagher and Reid (1979), the veliger larva remains in the water column for 8-10 weeks until they reach the final larval stage (pediveliger), at which time they search for a suitable place to settle and metamorphose into juvenile snails.

The maximum age of $L$. angulifera is unknown, but what is known is that the species can reach up to around $30 \mathrm{~mm}$ of shell height (Matthews-Cascon and Lotufo, 2006), which was confirmed in the present study, where we obtained average height of $17 \mathrm{~mm}$ in M1 and $21.8 \mathrm{~mm}$ in M2, with the largest individuals (outliers) in both mangroves slightly exceeding $30 \mathrm{~mm}$. Gutierrez (1988) observed a 
Table 4. Monthly mean values of shell height $(\mathrm{mm})$ and standard deviation $( \pm$ SD) throughout 2018 of Littoraria angulifera, indicating, in parentheses, the smallest and largest individual in the samples, and showing the p values (by Tukey test with decision level of $\alpha=0.05$ ) where * indicates significantly different results ( $<<0.05$ ), in two mangroves (M1 and M2) in the coast of Bahia State, northeastern Brazil.

\begin{tabular}{|c|c|c|c|c|c|c|}
\hline \multirow{3}{*}{ Months } & \multicolumn{6}{|c|}{ Mangroves } \\
\hline & \multicolumn{3}{|c|}{ M1 } & \multicolumn{3}{|c|}{ M2 } \\
\hline & Males & Females & $p$ values & Males & Females & p values \\
\hline Jan & $\begin{array}{c}18.41 \pm 4.38 \\
(6.58-30.23)\end{array}$ & $\begin{array}{c}15.91 \pm 4.75 \\
(5.39-30.22)\end{array}$ & $0.0000^{*}$ & $\begin{array}{c}22.04 \pm 2.15 \\
(14.3-28.25)\end{array}$ & $\begin{array}{c}22.07 \pm 2.3 \\
(15.44-29.72)\end{array}$ & 0.8848 \\
\hline Feb & $\begin{array}{c}18.68 \pm 3.2 \\
(10.71-27.8)\end{array}$ & $\begin{array}{c}17.63 \pm 4.32 \\
(7.13-28.95)\end{array}$ & $0.0210^{*}$ & $\begin{array}{c}21.94 \pm 2.1 \\
(16.24-27.93)\end{array}$ & $\begin{array}{c}22.2 \pm 2.15 \\
(14.7-27.13)\end{array}$ & 0.3019 \\
\hline Mar & $\begin{array}{c}19.5 \pm 4.37 \\
(8.45-29.99)\end{array}$ & $\begin{array}{c}17.86 \pm 5.46 \\
(7.21-30.35)\end{array}$ & $0.0148^{*}$ & $\begin{array}{c}21.7 \pm 2.16 \\
(15.05-27.58)\end{array}$ & $\begin{array}{c}21.54 \pm 2.35 \\
(15.27-30.63)\end{array}$ & 0.5414 \\
\hline Apr & $\begin{array}{l}15.56 \pm 4.27 \\
(5.6-24.68)\end{array}$ & $\begin{array}{l}14.19 \pm 4.52 \\
(0.55-25.4)\end{array}$ & $0.0011^{*}$ & $\begin{array}{c}22.88 \pm 2.54 \\
(10.89-29.38)\end{array}$ & $\begin{array}{l}23.46 \pm 2.69 \\
(11.0-29.7)\end{array}$ & 0.1651 \\
\hline May & $\begin{array}{l}18.19 \pm 3.88 \\
(8.74-24.4)\end{array}$ & $\begin{array}{l}16.64 \pm 4.49 \\
(7.37-25.6)\end{array}$ & $0.0110^{*}$ & $\begin{array}{c}22.19 \pm 2.45 \\
(13.69-26.2)\end{array}$ & $\begin{array}{c}21.54 \pm 4.19 \\
(9.34-30.82)\end{array}$ & 0.2114 \\
\hline June & $\begin{array}{c}17.78 \pm 3.08 \\
(11.19-25.29)\end{array}$ & $\begin{array}{c}16.51 \pm 3.86 \\
(8.36-26.47)\end{array}$ & $0.0022^{*}$ & $\begin{array}{c}22.02 \pm 3.07 \\
(10.97-29.08)\end{array}$ & $\begin{array}{c}20.64 \pm 4.49 \\
(9.12-28.66)\end{array}$ & $0.0191^{*}$ \\
\hline July & $\begin{array}{c}16.16 \pm 3.5 \\
(8.5-23.55)\end{array}$ & $\begin{array}{l}14.59 \pm 3.81 \\
(6.6-24.0)\end{array}$ & $0.0050^{*}$ & $\begin{array}{c}21.09 \pm 4.3 \\
(11.42-29.9)\end{array}$ & $\begin{array}{c}20.91 \pm 4.97 \\
(9.58-31.62)\end{array}$ & 0.7857 \\
\hline Aug & $\begin{array}{c}18.87 \pm 3.18 \\
(10.93-24.54)\end{array}$ & $\begin{array}{c}17.98 \pm 3.85 \\
(8.54-29.25)\end{array}$ & 0.0062 & $\begin{array}{c}23.26 \pm 3.52 \\
(10.86-28.73)\end{array}$ & $\begin{array}{l}22.25 \pm 5.23 \\
(8.11-32.12)\end{array}$ & 0.1071 \\
\hline Sep & $\begin{array}{c}16.06 \pm 4.09 \\
(7.03-23.77)\end{array}$ & $\begin{array}{c}15.11 \pm 4.86 \\
(5.68-26.74)\end{array}$ & 0.1432 & $\begin{array}{c}22.46 \pm 3.19 \\
(13.07-29.93)\end{array}$ & $\begin{array}{c}21.16 \pm 4.55 \\
(12.19-33.28)\end{array}$ & $0.0042^{*}$ \\
\hline Oct & $\begin{array}{c}17.73 \pm 4.34 \\
(6.83-26.23)\end{array}$ & $\begin{array}{c}16.46 \pm 4.51 \\
(6.75-25.49)\end{array}$ & 0.0526 & $\begin{array}{c}22.06 \pm 4.17 \\
(10.86-29.62)\end{array}$ & $\begin{array}{c}22.05 \pm 4.67 \\
(9.76-32.12)\end{array}$ & 0.9821 \\
\hline Nov & $\begin{array}{c}18.5 \pm 4.94 \\
(2.03-29.99)\end{array}$ & $\begin{array}{c}16.77 \pm 5.18 \\
(5.94-29.97)\end{array}$ & $0.0329^{*}$ & $\begin{array}{c}21.79 \pm 3.65 \\
(12.34-28.09)\end{array}$ & $\begin{array}{c}20.32 \pm 4.56 \\
(9.58-28.85)\end{array}$ & $0.0324^{*}$ \\
\hline Dec & $\begin{array}{c}16.69 \pm 3.72 \\
(7.13-22.75)\end{array}$ & $\begin{array}{c}16.4 \pm 4.74 \\
(6.37-25-35)\end{array}$ & 0.7493 & $\begin{array}{c}21.67 \pm 2.08 \\
(16.24-27.48)\end{array}$ & $\begin{array}{c}22.04 \pm 2.08 \\
(14.7-28.42)\end{array}$ & 0.2392 \\
\hline
\end{tabular}

mean height of $18 \mathrm{~mm}$ in a study in Panama and Chaves (unpublished data) $21.3 \mathrm{~mm}$ in Ubatuba, north coast of the state of São Paulo (Brazil). Zeidan et al. (2020) obtained averages of about $15 \mathrm{~mm}$ in samples collected on artificial substrates (concrete walls), according to these authors visibly impacted, and above $20 \mathrm{~mm}$ in well-preserved mangroves on the southern coast of the state of Bahia, northeastern Brazil.

Males were slightly larger than females in both populations, with differences that were statistically significant in several months, mainly in M1, which may be related to a greater investment, by females, of energy for reproduction (oogenesis) at the expense of growth. As reviewed by Riascos and Guzman (2010), in organisms such as mollusks there is a gradual decline in the energy reserved for growth and a corresponding increase in energy destined to reproduction.

On the other hand, there was a slight predominance of females over males in both populations. According to
Maxwell et al. (2017), a significant sex imbalance favoring females occurs in many gastropods populations and it seems to have various causes. When reviewing the causes of the sex ratio variation in some species of mollusks, Yusa (2009) considered that there is a great variation of this parameter within the same species, which seems to be influenced by several factors, including environmental determinants. On the southern coast of Bahia, Zeidan et al. (2020) found different results regarding the sex ratio in $L$. angulifera, but in general the means obtained by these authors pointed to proportions close to $1 \mathrm{M}$ : $1 \mathrm{~F}$. Still according to these authors, some more impacted areas had more females than males (sex ratio $\mathrm{M}$ : $\mathrm{F}<0.8$ ).

Littoraria angulifera seems to adapt well to conditions with a significant range of variation of salinity, which was observed in the two mangroves, which showed a tendency to great dilution of rivers adjacent to the forest. Chaves (2002) mentioned that L. angulifera has a preference for more saline areas, but that the species is also found 

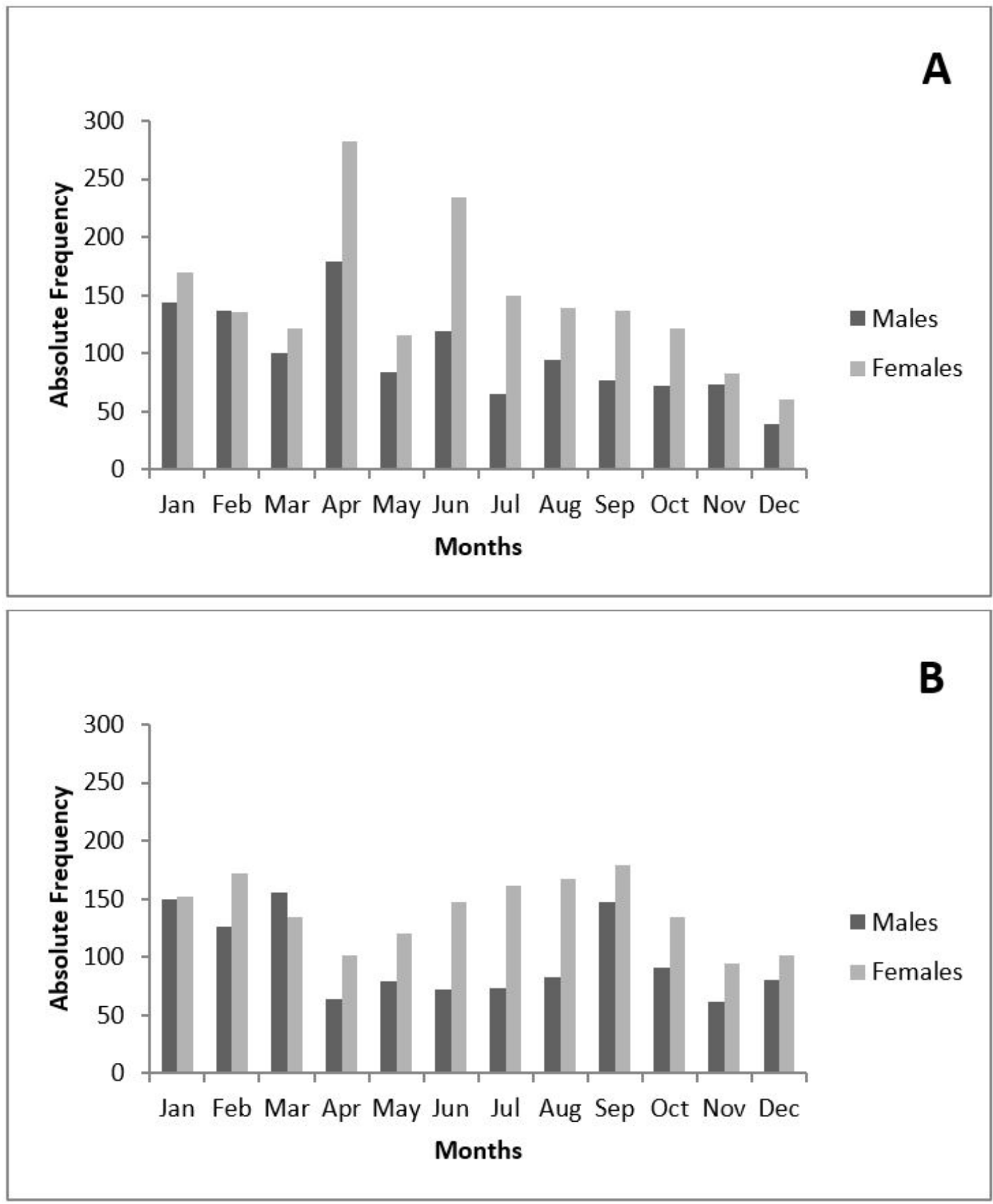

Figure 2. Monthly absolute frequency of males and females of Littoraria angulifera collected throughout 2018 on trunks of Rhizophora mangle in two localities (A = M1; B = M2) in the coast of the Bahia State, northeastern Brazil.

in lower salinities, which was confirmed in the present study, where the values were generally low (below 15 on M1 and below 25 on M2).

As for the vertical distribution on the trunks of $R$. mangle, although $L$. angulifera is distributed up to about $2 \mathrm{~m}$ in height, its preference for strata close to the ground, more shaded, was evident. This preference was verified for both sexes, discarding our hypothesis that females occupy more basal strata, supposedly where they would find it easier to lay eggs and larvae. It was also not observed that larger animals occupy higher strata on the trunks, the Type 1 distribution described by Vermeij (1973) for gastropods at the upper levels of marine rocky shores, zones in which individuals would be larger, but less numerous. According to 


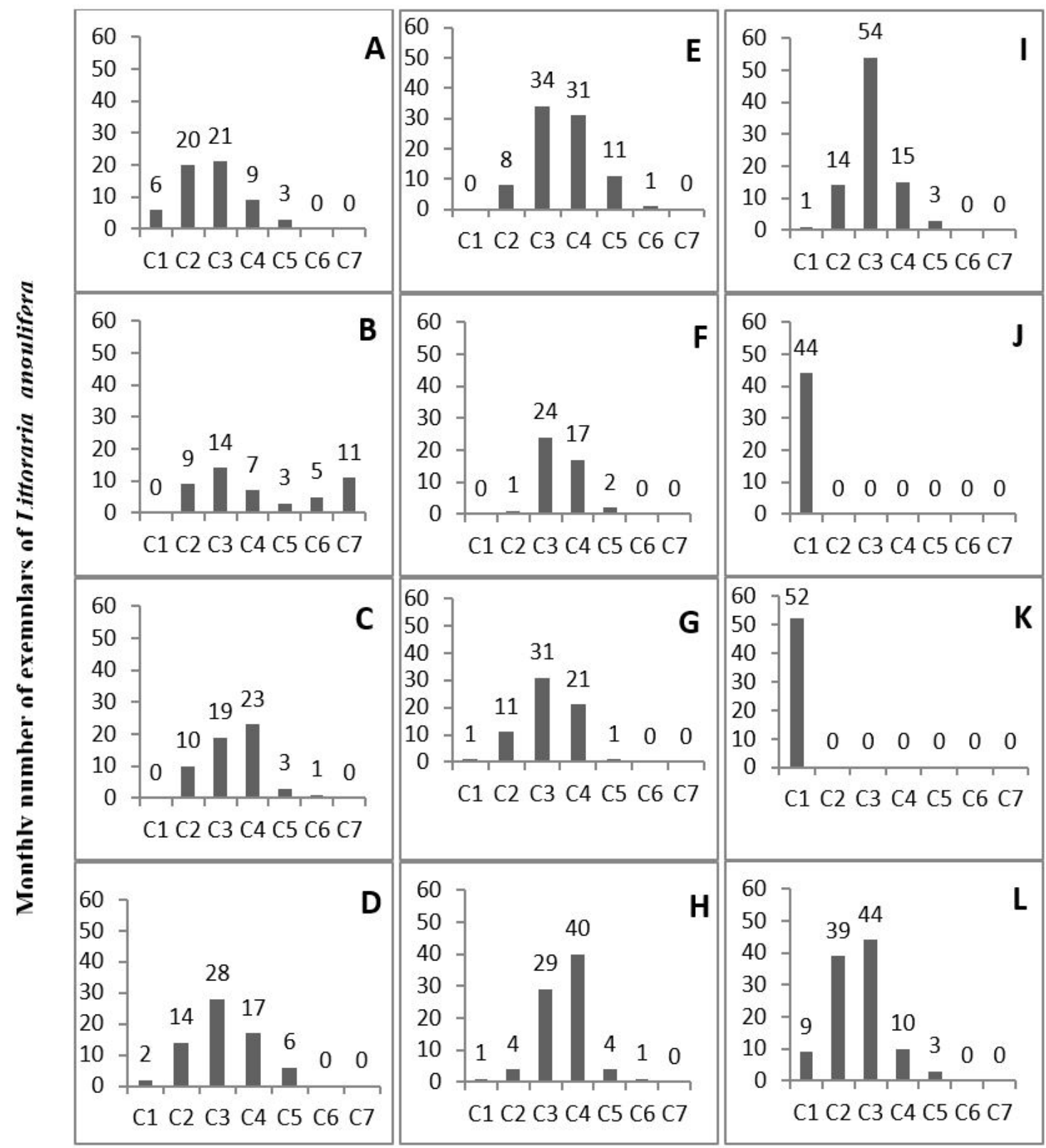

\section{Monthly size classes}

Figure 3. Total specimens of Littoraria angulifera collected monthly throughout 2018 on the grass Spartina alterniflora in a mangrove (M1) in Ilhéus, Bahia State, northeastern Brazil, distributed by size classes (shell height), being: C1 (less than 2.99 mm), C2 (3-5.9 mm), C3 (6-8.99 mm), C4 (9-11.99 mm), C5 (12-14.99 mm), C6 (15-17.99 mm) and C7 (18-20.99 mm); A-L: January to December.

this author, larger animals could more easily occupy these levels because they have a smaller relationship between the surface and the volume of the body, which would enable them to have greater water retention, consequently to greater cooling and less risk of desiccation, increasing their ability to survive. Chaves (2002) observed this type of distribution in L. angulifera on the south coast of the state of São Paulo and the same was observed for the species by Maia et al. (2010) in estuaries in Ceará, northeastern Brazil. All authors observed a greater number of individuals at a height closer to the substrate and larger animals at higher places in the tree. The results of the present study converged with those of these authors only in terms of the number of animals, not in relation to the size of the animals.

Although we found a significantly larger number of animals at height 1 (H1) (0-1 $\mathrm{m}$ in height of the trunk), 
it is certain that a considerable number of animals were also seen in $\mathrm{H} 2$ (1-2 $\mathrm{m}$ in height). The occupation of higher levels of the substrate by a part of the animals may be related to intra-specific competition for space and food. With regard to feeding, it is possible that higher strata of the trunks cyclically present a greater amount of lichens and fungi available to the snails in relation to the most basal part of the trunks, where the grazing pressure is supposedly greater, given the greater amount of animals in that place. It must be taken into account that these animals have good mobility, which potentially allows them to enter the substrate throughout the day, related not only to feeding, but also to mating, as well as to avoid predation and immersion. In this last aspect, $L$. angulifera does not support long periods of immersion because it has poorly developed gills. Zeidan (unpublished data) observed this lack of tolerance to immersion in the laboratory, reporting the death of animals after prolonged periods of submersion. On the other hand, this species has a well vascularized epithelium, which allows it to absorb oxygen from the air (Gutierrez, 1988). It is likely that during periods of high tide, there will be some vertical displacement in the trunks to strata less close to the substrate, not flooded.

Considering only the period of emergence during low tide, it was evident in this study that L. angulifera protects itself from direct sunlight, a fact that most animals were found close to the ground, in a more shaded place, which is certainly related to a search for protection against desiccation. Larger and heavier animals in M2, a mangrove with greater shading compared to M1, indicate a population in a greater comfort zone, which allows for greater growth and weight accumulation in that area. Despite this physiological favoring, the study also showed that the sparse and shorter tree vegetation in M1 did not interfere in survival, since the abundance of this locality was similar to that seen in M2. Melo et al. (2012) also found significant differences in shell size among different estuaries in the state of Ceará (Brazil) and found a positive correlation between the height of the shell and the height of the tree. Previously, Merkt and Ellison (1998), when comparing material from museums, also interpreted that variations in the size and also in the shape of the shell would be a response to different degrees of exposure to solar radiation.

Regarding the horizontal spatial distribution of the species, no pattern was clear, since in M1 there were more animals in level 2 (farthest from the river) and in M2 more animals in level 1 (closest to the river). On the other hand, this result showed that the species is heterogeneously distributed in mangrove areas, perhaps responding to specific conditions of micro-habitats, already reported by Melo et al. (2012). The "patchy" distribution had also been reported by Chaves (2002) and certainly indicates a physiological and behavioral adaptation of the species in these environments. Still in this context, Gutierrez (1988) observed the presence of younger individuals near the waterline. Although we have not evidenced this fact, this may be related to the species' own ontogenetic process, since the phase before L. angulifera becomes plantigrade stage occurs in the water column, where the larvae develop until the pediveliger stage. So, the punctual proximity of post-larvae close to the waterline may mean their recent transition from the planktonic to the benthic stage.

The importance of the marine grass $S$. alterniflora was verified mainly as substrate for post-larvae and juveniles. Chaves (2002) had already verified the use of this substrate, together with $R$. mangle, by this species in the south coast of the state of São Paulo, southeast of Brazil, supposedly also by recruits, since the author carried out a study during a recruitment period.

In conclusion, the results obtained allowed us to affirm that the size of the trees of R.mangle and the size of their canopies influence both shell height and total weight of L. angulifera, that is, more shaded places provide greater growth and weight accumulation of the animals. However, this is not determinants in the size of populations, since the mangrove with the lowest and most sparse tree vegetation (M1) presented similar abundance to M2, with taller and closer trees. The mangrove corresponding to the M1 suffers some degree of anthropic impact, such as deposition of garbage and domestic sewage, due to the presence of a balneary and houses in the vicinity of the mangrove, but apparently there is no deforestation in the area. On the contrary, M2 is still a very preserved area, with low anthropic activity, being one of the most intact mangroves in the region. This tells us about the great importance of preserving mangroves systems and their important biota in tropical regions. Although there is no specific knowledge about the predators of L. angulifera, Reid (1985) reports that these snails are preyed on by birds, crustaceans, parasitic flies and fish. Like this, this range of predators increases the ecological importance of the species in these systems. Due to its abundance and exclusive occurrence in mangroves, this snail also has great potential for assessing coastal regions for chemical contaminants and other pollutants, which also elevates its importance in bio-monitoring programs.

\section{Acknowledgements}

The authors would like to thank Luciano S. Barbosa, Sandra A. Freitas and Paulo R. Silva Jr. for helping with the sampling work; Virginia M. Silva for aid in laboratory processing; Ricardo L. Viana, for making the map; to CAPES-Brazil, for the grant of the master's scholarship to the second author.

\section{References}

ABBOTT, R.T. and MORRIS, P.A., 1995. A field guide to shells: Atlantic and Gulf coasts and the West Indies (The Peterson Field Guide). 4th ed. Boston: Houghton Mifflin.

BOEHS, G., MONTEIRO ABSHER, T. and DA CRUZ-KALED, A., 2004. Composition and distribution of benthic molluscs on intertidal flats of Paranaguá Bay (Paraná, Brazil). Scientia Marina, vol. 68, no. 4, pp. 537-543. http://dx.doi.org/10.3989/ scimar.2004.68n4537.

BURGETT, J.M., CUBIT, J.D. and THOMPSON, R.C., 1987. Seasonal growth patterns in the tropical littorinid snails Littorina angulifera and Tectarius muricatus. The Veliger, vol. 30, no. 1, pp. 11-23. 
CHAVES, A.M.R., 2002. Entre o seco e o molhado, do costão ao manguezal: distribuição de gastrópodes da família Littorinidae em gradientes vertical e horizontal no litoral do estado de São Paulo. Campinas: Universidade Estadual de Campinas, 144 p. Dissertação de Mestrado no Instituto de Biologia.

CLIMATEMPO [online], 2020 [viewed 06 November 2020]. Available from: www.climatempo.com.br.

COSTA, M.B., ZAMPROGNO, G.C., PEDRUZZI, F.C., DALBEM, G.B. and TOGNELLA, M.M.P., 2013. Assessing the continuous impact of Tributyltin from Antifouling Paints in a Brazilian mangrove area using Intersex in Littoraria angulifera (Lamarck, 1822) as Biomarker. International Journal of Oceanography, vol. 2013, no. 1, pp. 1-8. http://dx.doi.org/10.1155/2013/769415.

GALLAGHER, S.B. and REID, G.K., 1979. Population dynamics and zonation in the periwinkle snail, Littorina angulifera, of the Tampa Bay, Florida region. The Nautilus, vol. 94, no. 1, pp. 162-178.

GALTSOFF, P.S., 1961. Physiology of reproduction in Molluscs. American Zoologist, vol. 1, no. 1, pp. 273-289. http://dx.doi. org/10.1093/icb/1.2.273.

GUTIERREZ, P.C., 1988. The ecology and behavior of the mangrove periwinkle, Littoraria angulifera. Biotropica, vol. 20, no. 4, pp. 352-356. http://dx.doi.org/10.2307/2388333.

KOHLMEYER, J. and BEBOUT, B., 1986. On the occurrence of marine fungi in the diet of Littorina angulifera and observations on the behavior of the periwinkle. Marine Ecology (Berlin), vol. 7, no. 1, pp. 333-343. http://dx.doi. org/10.1111/j.1439-0485.1986.tb00168.x.

MAIA, R.C., LIMA-VERDE, F.B. and ROLEMBERG, K.F., 2010. Padrões de distribuição vertical e horizontal de Littoraria angulifera (Lamarck, 1822) nos estuários dos rios Ceará e Pacoti, estado do Ceará. Arquivo de Ciências Marinhas, vol. 43, no. 1, pp. 32-39. http://dx.doi.org/10.32360/acmar.v43i2.5992.

MARTÍNEZ, S., MAHIQUES, M.M. and BURONE, L., 2013. Mollusks as indicators of historical changes in an estuarine-lagoonal system (Cananéia-Iguape, SE, Brazil). The Holocene, vol. 23, no. 1, pp. 888-897. http://dx.doi.org/10.1177/0959683612470175.

MATTHEWS-CASCON, H. and LOTUFO, T.M.C., 2006. Biota marinha da costa oeste do Ceará. Brasília: MMA, 248 p., Série Biodiversidade, vol. 24 , no. 1 .
MAXWELL, S.J., RYMER, T.L. and CONGDON, B.C., 2017. Sex-ratio bias in Laevistrombus canarium Linné, 1758 (Gastropoda: Strombidae) from Far North Queensland, Australia. Memoirs of the Queensland Museum, vol. 60, no. 1, pp. 133-138. http:// dx.doi.org/10.17082/j.2204-1478.60.2017.2016-15.

MELO, C.G.B., MAIA, R.C. and ROCHA-BARREIRA, C.A., 2012. Shell morphology variation and population density of Littoraria angulifera (Mollusca: Gastropoda) in mangrove forests of Ceará State, Brazil. Arquivo de Ciências Marinhas, vol. 45, no. 1, pp. 68-76.

MERKT, R.E. and ELLISON, A.M., 1998. Geographic and habitat-specific morphological variation of Littoraria (Littorinopsis) angulifera (Lamarck, 1822). Malacologia, vol. 40, no. 1-2, pp. 279-295.

REID, D.G., 1985. Habitat and zonation patterns of Littoraria species (Gastropoda: Littorinidade) in Indo-Pacific mangrove forests. Biological Journal of the Linnean Society. Linnean Society of London, vol. 26, no. 1, pp. 39-68. http://dx.doi. org/10.1111/j.1095-8312.1985.tb01551.x.

RIASCOS, J.M. and GUZMAN, P.A., 2010. The ecological significance of growth rate, sexual dimorphism and size at maturity of Littoraria zebra and L. variegata (Gastropoda: littorinidae). The Journal of Molluscan Studies, vol. 76, no. 3, pp. 289-295. http:// dx.doi.org/10.1093/mollus/eyq011.

RIOS, E.C., 2009. Compendium of brazilian sea shells. Rio Grande: Evangraf.

VERMEIJ, G.J., 1973. Molluscs in mangrove swamps: physiognomy, diversity and regional differences. Systematic Zoology, vol. 22, no. 4, pp. 609-624. http://dx.doi.org/10.2307/2412965.

YUSA, Y., 2009. Causes of variation in sex ratio and modes of sex determination in the Mollusca - an overview. American Malacological Bulletin, vol. 23, no. 1, pp. 89-98. http://dx.doi. org/10.4003/0740-2783-23.1.89.

ZEIDAN, G.C., BARROSO, C.M. and BOEHS, G., 2018. Efficiency of anesthetics on female gastropod Littoraria angulifera. Boletim do Instituto de Pesca, vol. 44, no. 3, pp. e304. http://dx.doi. org/10.20950/1678-2305.2018.304.

ZEIDAN, G.C., FREITAS, L.A., SANTOS, G.B.M., SILVA-NETO, E.M. and BOEHS, G., 2020. Morphometric analysis of Littoraria angulifera (Caenogastropoda) in estuarine regions of northeastern Brazil. Brazilian Journal of Biology = Revista Brasileira de Biologia, vol. 80, no. 2, pp. 424-430. http://dx.doi.org/10.1590/1519-6984.214187. PMid:31482972. 